\title{
UPAYA PEMULIHAN SEKTOR PARIWISATA DI TENGAH PANDEMI COVID 19
}

\author{
Ni Ketut Sutrisnawati ${ }^{1}$, Ni Gusti Ayu Nyoman Budiasih ${ }^{2}$, I Ketut Ardiasa ${ }^{3}$ \\ Akademi Pariwisata Denpasar ${ }^{1}$ \\ Email: nksutrisnawati@gmail.com, \\ Akademi Pariwisata Denpasar ${ }^{2}$ \\ Email: gustiayubudiasih86@gmail.com, \\ Akademi Pariwisata Denpasar ${ }^{3}$ \\ Email: iketutardiasa39@gmail.com
}

Received: August 12, 2020 | Accepted: September 10, 2020 | Published: Nov. 2, 2020

Permalink/DOI: https://doi.org/10.53356/diparojs.v1i1.21

\begin{abstract}
ABSTRAK
Sektor Pariwisata merupakan sektor yang sangat penting bagi masyarakat Bali. Walaupun wilayah Bali terdiri dari lahan pertanian, lahan kering serta perairan seperti pantai, danau,dan sungai, namun sebagian besar masyarakat Bali menggantungkan kehidupannya dari sektor Pariwisata. Pandemi Covid -19 memberikan pukulan yang sangat keras bagi semua sektor termasuk sektor pariwisata. Virus Corona yang sangat membahayakan kesehatan manusia telah menginfeksi jutaan penduduk di seluruh dunia. Penyebaran virus Corona melalui interaksi dengan orang yang telah terinfeksi menyebabkan adanya kebijakan pembatasan jarak sosial, serta anjuran untuk melakukan aktivitas di rumah. Kebijakan yang dibuat untuk mencegah efek domino dan memutus penyebaran virus ini perlahan namun pasti telah menghantam sektor pariwisata. Tidak adanya kunjungan wisatawan mancanegara serta pembatasan wilayah di Indonesia menyebabkan berbagai usaha pariwisata mengalami dampak yang luar biasa. Hotel-hotel dengan hunian $0 \%$ di tutup untuk sementara waktu. Para karyawan hotel, travel dan usaha perjalanan wisata, restoran, serta sektor lainnya pun dirumahkan dan sebagian besar kehilangan pekerjaan. Ambruknya sektor pariwisata di Bali menyebabkan merosotnya perekonomian Bali. Tidak saja pekerja disektor pariwisata, namun para petani yang memasok hasil pertaniannya ke hotel maupun restoran, nelayan yang menjual hasil tangkapan ikannya ke hotel, serta menengah (UMKM) terutama yang menghasilkan cendera mata ikut terkena imbasnya. Hal ini tentu tidak boleh dibiarkan terus berlarut-larut karena akan mempengaruhi kelanjutan hidup masyarakat Bali. Penelitian ini bertujuan untuk mengetahui dampak yang di timbulakn oleh COVID-19 terhadap sektor parisata beserta Upaya-upaya yang dapat dilakukan untuk pemulihan pariwisata dalam upaya memulihkan perkonomian masyarakat Bali agar masyarakat Bali dapat melanjutkan kehidupan seperti sediakala.
\end{abstract}

Kata Kunci: Pariwisata, Dampak negatif, Pemulihan, COVID-19, Perekonomian, Bali

\section{ABSTRACT}

The tourism sector is a very important sector for the people of Bali. Although the Bali region consists of agricultural land, dry land and waters such as beaches, lakes and rivers, most Balinese depend their livelihoods on the tourism sector. Pandemic Covid -19 give a deep impact to all sectors including the tourism sector. Corona virus which is very dangerous to human health has infected millions of people around the world. The spread of the Corona virus through interactions with infected people is the reason of why social distance, as well as suggestions for activities at home policies made to prevent the domino effect and sever the spread of this virus. Slowly but surely the pandemi hit the tourism sector. The absence 
of foreign tourist visits and lockdown in some areas in Indonesia has caused tremendous impacts to tourism sector. Hotels with 0\% occupancy are temporary closed. Employees of hotels, travel and tourist businesses, restaurants and other sectors were laid off and most lost their jobs. The collapse of the tourism sector in Bali caused the decline of the Balinese economy. Not only workers in the tourism sector, but farmers who supply their agricultural products to hotels and restaurants, fishermen who sell their fish catches to hotels, as well as medium (MSME) especially those who produce souvenirs are affected. This certainly should not be allowed to continue protracted because it will affect the continuation of life of the Balinese people. This study aims to determine the impact caused by COVID-19 on the tourism sector along with the efforts that can be made to restore tourism in an effort to restore the economy of the Balinese people so that Balinese people can continue their lives as before.

Key words: Tourism, Negative Impact, Recovery, COVID-19, Economy, Bali

\section{PENDAHULUAN}

Pariwisata telah menjadi bagian yang tidak terpisahkan dalam kehidupan manusia. Kegiatan berwisata yang dulu hanya dinikmati oleh segelintir orang kini telah dinikmati oleh sebagian besar penduduk di dunia. Berwisata kini telah menjadi suatu kebutuhan. Berbagai alasan untuk melakukan kegiatan wisata antara lain untuk menghilangkan kejenuhan akibat rutinitas yang monoton, kemajuan teknologi yang memudahkan akses serta informasi tentang suatu destinasi, meningkatkan rasa percaya diri dengan memposting foto dokumentasi ke media sosial serta berbagai alasannya lainnya.

Dengan meningkatnya animo masyarakat untuk berwisata telah menjadikan industri pariwisata tumbuh menjadi salah satu industri terbesar dan merupakan salah satu sektor ekonomi yang tumbuh paling cepat di dunia. Menurut organisasi OECD dalam OECD Tourism Trends and Policies 2020 mengungkapkan bahwa pariwisata adalah sektor ekonomi yang sangat signifikan secara global dan lokal, dan memberikan prospek nyata untuk pertumbuhan ekonomi inklusif dan berkelanjutan. Sektor ini menghasilkan devisa, mendorong pembangunan daerah, secara langsung mendukung berbagai jenis pekerjaan dan bisnis dan menopang banyak komunitas lokal. Tren terbaru menunjukkan pertumbuhan kuat yang berkelanjutan di seluruh dunia. Lebih lanjut OECD menyatakan bahwa pariwisata global terus berkembang selama lebih dari enam dekade. Didorong oleh pertumbuhan ekonomi global yang kuat dan pasar outbound, khususnya dari kawasan Asia Pasifik, kedatangan wisatawan internasional di seluruh dunia tumbuh menjadi lebih dari 1,4 miliar pada tahun 2018, meningkat 5,6\% pada 2017. Secara global penerimaan perjalanan internasional pada tahun 2018 mengalami pertumbuhan sebesar $4,8 \%$ dibanding tahun 2017. Pengeluaran global untuk perjalanan telah meningkat lebih dari tiga kali lipat sejak pergantian abad, naik menjadi 1,5 triliun dolar AS pada tahun 2018 dan menyumbang $7 \%$ dari ekspor global barang dan jasa (UNWTO, 2019b, 2020). Menurut perkiraan Organisasi Perdagangan Dunia baru-baru ini, pariwisata adalah sektor jasa perdagangan terbesar kelima (WTO, 2019 dalam OECD 2020).

Sektor pariwisata merupakan salah satu penyumbang devisa terbesar bagi Indonesia. Dalam Rencana Pembangunan Jangka Menengah Nasional (RPJMN) 2015-2019 yang menetapkan 5 (lima) fokus program pembangunan 5 (lima) tahun ke depan yaitu Infrastruktur, Maritim, Energi, Pangan dan Pariwisata (IMEPP). Dari lima sektor tersebut pariwisata ditetapkan sebagai sektor unggulan (leading sector). 
Tabel 1

Capaian Sektor Pariwisata 2015-2018

\begin{tabular}{|l|l|l|l|l|l|l|l|l|}
\hline \multicolumn{1}{|c|}{ Indikator } & \multicolumn{2}{|c|}{$\mathbf{2 0 1 5}$} & \multicolumn{2}{c|}{$\mathbf{2 0 1 6}$} & \multicolumn{2}{c|}{$\mathbf{2 0 1 7}$} & \multicolumn{2}{|c|}{$\mathbf{2 0 1 8}$} \\
\cline { 2 - 10 } & $\begin{array}{c}\text { Tar- } \\
\text { get }\end{array}$ & $\begin{array}{c}\text { Real- } \\
\text { isasi }\end{array}$ & $\begin{array}{c}\text { Tar- } \\
\text { get }\end{array}$ & $\begin{array}{c}\text { Real- } \\
\text { isasi }\end{array}$ & Target & $\begin{array}{c}\text { Real- } \\
\text { isasi }\end{array}$ & $\begin{array}{c}\text { Tar- } \\
\text { get }\end{array}$ & $\begin{array}{c}\text { Real- } \\
\text { isasi }\end{array}$ \\
\hline $\begin{array}{l}\text { Kontribusi Pada PDB } \\
\text { Nasional }\end{array}$ & $4,23 \%$ & $4,25 \%$ & $4,50 \%$ & $4,13 \%$ & $5 \%$ & $5 \%$ & $5,25 \%$ & $5,25 \%$ \\
\hline Devisa (Triliun Rp) & 144 & 175,71 & 172 & 176,23 & 200 & 202,13 & 223 & 224 \\
\hline $\begin{array}{l}\text { Jumlah Tenaga Kerja } \\
\text { (Juta Orang) }\end{array}$ & 11,4 & 10,36 & 11,8 & 12,28 & 12,0 & 12,60 & 12,6 & 12,7 \\
\hline $\begin{array}{l}\text { Indeks Daya Saing } \\
\text { (WEF) }\end{array}$ & $\# 50$ & $\# 50$ & n.a & n.a & $\# 40$ & $\# 42$ & n.a & n.a \\
\hline $\begin{array}{l}\text { Wisatawan } \\
\text { Mancanegara (Juta } \\
\text { Kunjungan) }\end{array}$ & 10 & 10,41 & 12 & 12,02 & 15 & 14,04 & 17 & 15,81 \\
\hline $\begin{array}{l}\text { Wisatawan Nusan- } \\
\text { tara (Juta Perjalanan) }\end{array}$ & 255 & 256,42 & 260 & 264,33 & 265 & 270,82 & 270 & 303,5 \\
\hline
\end{tabular}

Sumber: eperformance.kemenpar.go.id

Dari tabel 1 diatas dapat kita lihat bahwa dari tahun 2016 -2018 pariwisata memberikan kontribusi pada PDB serta devisa yang meningkat dari tahun ke tahun. Demikian pula terjadi penyerapan tenaga kerja yang terus meningkat hal ini disebabkan karena terus bertambahnya kunjungan wisatawan baik mancanegara maupun wisatawan nusantara yang berwisata di Indonesia.

Pulau Bali dengan berbagai potensi alam dan budaya yang dimiliki merupakan salah satu destinasi wisata andalan Indonesia. Tidak hanya di Indonesia namun keindahan Bali telah tersebar hingga ke pelosok dunia. Pesatnya perkembangan pariwisata di Bali diiringi oleh besarnya manfaat ekonomi yang dirasakan bagi sebagian besar masyarakat Bali sehingga menjadikan sektor pariwisata menjadi sektor unggulan di bandingkan dengan dengan sektor pertanian dan perikanan.

Walaupun sektor pariwisata memberikan manfaat ekonomi yang sangat signifikan namun sektor pariwisata merupakan sektor jasa yang sangat peka terhadap berbagai isu seperti isu politik, sosial, keamanan, lingkungan. Pariwisata Bali mengalami beberapa ujian dengan adanya isu terorisme dengan adanya bom Bali di tahun 2002 yang telah menyebabkan ketakutan wisatawan untuk berkunjung ke Bali. Perlahan Bali mampu mengembalikan citra sebagai destinasi wisata yang aman untuk di kunjungi. Di akhir tahun 2017 kembali pariwisata Bali mengalami penurunan dikarenakan oleh bencana alam berupa letusan gunung Agung yang menyebabkan tingkat hunian hotel turun di bawah 50\%. Tidak cukup sampai disini, pariwisata kembali mendapat cobaan yang sangat berat di sebabkan oleh penyebaran virus Corona yang pada awal mulanya muncul di negara Cina di akhir tahun 2019.

Pandemi COVID-19 telah menyebar ke seluruh negara di dunia. Penyebaran virus yang sangat membahayakan kesehatan manusia telah menginfeksi jutaan umat manusia di dunia. Penyebaran virus Corona disinyair melalui tetesan kecil (droplet) dari 
hidung atau mulut pada saat batuk atau bersin. Bertambahnya jumlah masyarakat dunia yang terinfeksi menyebabkan berbagai kebijakan dibuat untuk mengurangi efek domino serta memutus penyebaran virus ini, antara lain social distancing (pembatasan sosial), lockdown (karantina wilayah) serta work from home (bekerja/beraktifitas dari rumah).

Adanya kebijakan-kebijakan tersebut serta ketakutan masyarakat akan virus Corona telah menyebabkan pengurangan kegiatan bepergian masyarakat dunia. Hal ini berdampak pada menurunnya bahkan tidak adanya kunjungan wisatawan ke Bali selama pandemi. Hal ini memberikan pukulan yang sangat keras bagi industri pariwisata secara global termasuk industri pariwisata di Bali.

Melihat kondisi tersebut sangat perlu dilakukan upaya-upaya untuk memulihkan kembali sektor pariwisata khususnya di Bali dalam upaya memulihkan perekonomian masyarakat Bali. Adapun rumusan masalah dalam tulisan ini antara lain:

a. Bagaimana dampak dari pandemi Covid19 terhadap sektor pariwisata.

b. Upaya-upaya apa saja yang dapat dilakukan untuk memulihkan sektor Pariwisata di Bali.

\section{KAJIAN LITERATUR}

\subsection{Pariwisata}

Secara etimologis, istilah pariwisata berasal dari bahasa sansekerta yang terdiri dari dua suku kata yaitu "pari" dan "wisata". Pari berarti berulang-ulang atau berkali-kali, sedangkan wisata berarti perjalanan atau bepergian. Jadi pariwisata berarti perjalanan yang dilakukan secara berulang-ulang atau berkali-kali (Musanef, 1996 : 8). Menurut undang-undang nomor 10 tahun 209 tentang kepariwisataan Pariwisata adalah berbagai macam kegiatan wisata dan didukung berbagai fasilitas serta layanan yang disediakan oleh masyarakat, pengusaha, Pemerintah, dan Pemerintah Daerah. Sedangkan E. Guyer Freuler dalam Yoeti (1996: 115), menyatakan bahwa Pariwisata dalam artian modern adalah phenomena dari jaman sekarang yang didasarkan di atas kebutuhan akan kesehatan dan pergantian hawa, penilaian yang sadar dan menumbuhkan (cinta) terhadap keindahan alam dan pada khususnya disebabkan oleh bertambahnya pergaulan berbagai bangsa dan kelas masyarakat manusia sebagai hasil daripada perkembangan perniagaan, industri, perdagangan serta penyempurnaan daripada alat-alat pengangkutan.

Dari beberapa pengertian diatas dapat disimpulkan bahwa pariwisata merupakan perjalanan yang dilakukan secara berulangulang untuk memenuhi kebutuhan akan kesehatan dan pergantian hawa, penilaian yang sadar dan menumbuhkan (cinta) terhadap keindahan alam serta mempergunakan fasilitas yang disediakan baik oleh masyarakat, pengusaha maupun pemerintah.

Tujuan kepariwisataan Indonesia menurut Undang-undang Republik Indonesia nomor 10 tahun 2009 tentang Kepariwisataan, adalah untuk:

a. meningkatkan pertumbuhan ekonomi;

b. meningkatkan kesejahteraan rakyat;

c. menghapus kemiskinan;

d. mengatasi pengangguran;

e. melestarikan alam, lingkungan, dan sumber daya;

f. memajukan kebudayaan;

g. mengangkat citra bangsa;

h. memupuk rasa cinta tanah air;

i. memperkukuh jati diri dan kesatuan bangsa; dan

j. mempererat persahabatan antarbangsa.

\subsection{Pemulihan Bencana}

Pengertian Bencana menurut Undang-undang Nomor 24 Tahun 2007 Tentang 
Penanggulangan Bencana: adalah peristiwa atau rangkaian peristiwa yang mengancam dan mengganggu kehidupan dan penghidupan masyarakat yang disebabkan, baik oleh faktor alam dan/atau faktor nonalam maupun faktor manusia sehingga mengakibatkan timbulnya korban jiwa manusia, kerusakan lingkungan, kerugian harta benda, dan dampak psikologis. Bencana didefinisikan sebagai Suatu gangguan serius terhadap keberfungsian suatu masyarakat, sehingga menyebabkan kerugian yang meluas pada kehidupan manusia dari segi materi, ekonomi atau lingkungan dan yang melampaui kemampuan masyarakat yang bersangkutan untuk mengatasi dengan menggunakan sumberdaya mereka sendiri (ISDR, 2004). Dari dua definisi diatas dapat disimpulkan bahwa bencana adalah peristiwa baik yang disebabkan oleh faktor alam maupun non alam yang dapat mengancam dan membahayakan kehidupan dan keberfungsian masyarakat serta dapat menimbulkan kerugian baik materi maupun jiwa manusia. COVID-19 merupakan bencana non alam dan ditetapkan sebagai bencana nasional pada tanggal 13 April 2020 melalui Keputusan Presiden Republik Indonesia nomor 12 tahun 2020 tentang penetapan bencana non alam penyebaran corona virus disease 2019 (COVID-19).

Pemulihan bencana menurut Coppola dalam Herdiana (2020) diartikan sebagai "the emergency management function by which country, communities, families, and individual repairs, reconstruct, or regain what has lost as a result od disaster". Dapat diartikan bahwa pemulihan bencana fungsi fungsi manajemen darurat dimana negara, masyarakat, keluarga, dan individu memperbaiki, merekonstruksi, atau mendapatkan kembali apa yang telah hilang sebagai akibat dari bencana ". ini sejalan dengan pendapat dari Haas, Kates, \& Bowden (1977) dalam Herdiaia 2020, yang menyatakan bahwa pemulihan dapat diprediksi, terdiri dari bagian-bagian yang dapat diidentifikasi terjadi secara berurutan; pilihan dan keputusan didorong oleh nilai dan hasil menekankan kembali ke keadaan normal atau penggabungan tindakan-tindakan yang baru-baru ini dikaitkan dengan keberlanjutan. Dari kedua pendapat tersebut dapat disimpulkan bahwa pemulihan bencana merupakan upaya-upaya yang dilakukan baik oleh pemerintah, masyarakat, keluarga dan individu untuk mendapatkan kembali apa yang telah hilang karena bencana serta kembali ke keadaan normal.

\subsection{Pandemi}

Pengertian pandemi menurut WHO adalah penyebaran penyakit baru secara luas. Sedangkan pandemi menurut Itjen Kemendikbud adalah wabah yang berjangkit serempak di mana-mana, meliputi daerah geografis yang luas. Pandemi merupakan epidemi yang menyebar hampir di seluruh negara atau benua, biasanya mengenai banyak orang. Berdasarkan dari kedua definisi tentang pandemi diatas dapat disimpulkan bahwa pandemi merupakan penyebaran penyakit baru secara luas di seluruh dunia. Tanggal 11 Maret 2020, WHO menetapkan COVID-19 sebagai pandemi. Pada tanggal 14 Maret 2020 Indonesia menetapkan COVID-19 sebagai bencana nasional.

\subsection{Covid- 19}

Dalam situs kemenkes.go.id diuraikan bahwa Coronavirus merupakan keluarga besar virus yang menyebabkan penyakit ringan sampai berat, seperti common cold atau pilek dan penyakit yang serius seperti MERS dan SARS. Pengertian ini sama dengan pengertian yang diberikan oleh WHO yaitu Coronavirus adalah suatu kelompok virus yang dapat menyebabkan penyakit pada hewan atau manusia. Beberapa jenis coronavirus diketahui menyebabkan infeksi saluran 
nafas pada manusia mulai dari batuk pilek hingga yang lebih serius seperti Middle East Respiratory Syndrome (MERS) dan Severe Acute Respiratory Syndrome (SARS). Coronavirus jenis baru yang ditemukan menyebabkan penyakit COVID-19.

Dari definisi diatas dapat disimpulkan bahwa COVID-19 merupakan penyakit yang disebabkan oleh Coronavirus yang menyebabkan infeksi saluran nafas pada manusia mulai dari batuk pilek hingga yang lebih serius seperti Middle East Respiratory Syndrome (MERS) dan Severe Acute Respiratory Syndrome (SARS). Gejala-gejala yang ditunjukkan bagi orang terinfeksi COVID-19 yang paling umum adalah demam, batuk kering, dan rasa lelah. Gejala lainnya yang lebih jarang dan mungkin dialami beberapa pasien meliputi rasa nyeri dan sakit, hidung tersumbat, sakit kepala, konjungtivitis, sakit tenggorokan, diare, kehilangan indera rasa atau penciuman, ruam pada kulit, atau perubahan warna jari tangan atau kaki. Gejalagejala yang dialami biasanya bersifat ringan dan muncul secara bertahap. Beberapa orang menjadi terinfeksi tetapi hanya memiliki gejala ringan.

Adapun penularan COVID-19 melalui berbagai cara, yaitu:

a. Percikan ludah dari bersin atau batuk penderita COVID-19 yang masuk ke bagian, mata, mulut dan hidung.

b. menyentuh mulut, mata atau hidung tanpa mencuci tangan terlebih dulu setelah menyentuh benda yang terkena cipratan air liur penderita COVID-19

c. Kontak jarak dekat dengan penderita COVID-19, misalnya bersentuhan atau berjabat

\section{METODE PENELITIAN}

Mengacu pada rumusan masalah maka penelitian ini mempergunakan pendekatan deskriptif kualitatif. Pendekatan penelitian ini adalah pendekatan deskriptif kualitatif yang berlandaskan fenomenologis yaitu fenomena-fenomena atau relita ada di lapangan penelitian. Metode ini dipergunakan untuk menggambarkan atau melukiskan fakta-fakta atau kejadian yang terjadi selama pandemi COVID-19 yang berpengaruh terhadap sektor pariwisata di Bali.

Sumber data: data dalam tulisan ini di dapat secara online baik melalui situs resmi pemerintah seperti situs kemenpar melalui situs eperformance.kemenpar.go.id, data dari kementerian keuangan dalam situs https://jdih.kemen-

keu.go.id/fullText/2009/10TAHUN2009UU. HTM, data dari situs resmi WHO, situs resmi kemenkes RI, dari situs-situs lain seperti kompas.com serta berbagai jurnal ilmiah yang terkait, dll. Sedangkan objek penelitian dalam tulisan ini adalah isu, problem, atau permasalahan yang dibahas, dikaji, yang diteliti. Yang menjadi objek penelitian dalam tulisan ini adalah sektor pariwisata ditengah pandemi COVID-19.

\section{PEMBAHASAN}

Pandemi COVID-19 merupakan bencana non alam yang ditetapkan sebagai bencana nasional oleh pemerintah. Penyebaran COVID-19 yang sangat luas serta sangat berbahaya bagi kesehatan manusia secara perlahan telah sangat berpengaruh terhadap kehidupan manusia. Saat dunia menghadapi konsekuensi dahsyat pandemi COVID-19, sektor pariwisata termasuk yang paling parah terkena dampaknya. Perjalanan menurun, ketakutan meningkat, dan masa depan tidak pasti.

Sektor pariwisata merupakan mata pencaharian banyak orang terutama wanita khususnya di negara-negara yang paling rentan di dunia, termasuk pulau-pulau berkembang, Pulau-Pulau Kecil dan NegaraNegara yang kurang maju. 


\subsection{Dampak virus Corona terhadap Pari- Wisata}

Penyebaran virus yang terus meluas telah berdampak terhadap semua sektor termasuk sektor pariwisata secara global. COVID19 telah bergema di setiap sudut dunia, menyebabkan hilangnya nyawa dan pekerjaan serta kemerosotan dalam kegiatan ekonomi secara umum. Virus Corona yang awal mulanya tersebar di kota Wuhan, Cina, kina telah menyebar di 185 negara di dunia. Efek domino dari virus Corona menyebabkani virus ini menyebar dengan cepat. Berbagai kebijakan dibuat untuk mencegah dan menekan penyebaran virus Corona. Pemerintah mengeluarkan imbauan untuk melakukan pembatasan jarak dan pengurangan aktifitas diluar rumah serta pelarangan kegiatan yang mengakibatkan keramaian untuk memutus penyebaran virus ini. Larangan perjalanan serta lockdown diberlakukan diberbagai tempat yang telah terjangkit oleh virus ini.

Perlahan namun pasti, pandemi Corona telah memberikan dampak yang signifikan bagi semua sektor termasuk sektor pariwisata. Pariwisata selalu menjadi salah satu industri yang paling terpukul oleh pandemi dan krisis. Pandemi Corona memberikan pukulan yang sangat keras bagi sektor sektor pariwisata.

Industri pariwisata telah dipengaruhi secara besar-besaran oleh penyebaran Corona karena banyak negara memberlakukan pembatasan perjalanan dalam upaya untuk menahan penyebaran virus ini. Menurut World Travel and Tourism Council (WTTC) Sekitar 50 juta orang akan kehilangan pekerjaan di sektor pariwisata saja akibat pandemi virus corona ini.

Dampak Covid-19 terhadap sektor pariwisata dirasakan paling terburuk sepanjang sejarah. Pariwisata Bali yang sempat di guncang oleh meledaknya Bom Bali di tahun 2002 serta meletusnya gunung Agung di ta- hun 2017. Wakil Gubernur Bali Tjok Oka Artha Ardhana Sukawati mengatakan bahwa kerugiaan pariwisata Bali mencapai Rp 9,7 triliun setiap bulan. Merebaknya virus Corona telah menyebabkan hunian kamar hotel di Bali berada pada jumlah terendah sehingga menyebabkan hampir 90\% hotel di Bali ditutup sementara. Kepala Dinas Ketenagakerjaan Provinsi Bali Ida Bagus Ngurah Arda mengatakan, hingga tanggal 13 April 2020 ada 800 pekerja yang mengalami pemutusan hubungan kerja (PHK) serta 46.000 pekerja formal yang dirumahkan, angka ini diyakini terus bertambah selama pandemi COVID-19 belum berakhir.

Sebagai provinsi dengan luas hanya 0,19 persen dari luas wilayah indonesia, Bali tidak memiliki sumber daya alam yang bernilai ekonomi tinggi, seperti tambang, hutan dan sebagainya. Sumber daya yang dimiliki oleh pulau ini hanya berupa lahan sawah, lahan kering, perairan dan pantai yang dikembangkan untuk sektor pertanian, perikanan dan pariwisata. Keindahan alam serta keunikan budayanya menjadikan sektor pariwisata sebagai sektor primadona sehingga sebagian besar dari penduduk Bali menggantungkan hidup dari sektor pariwisata. Terguncangnya sektor pariwisata tentu saja mengguncang perekonomian masyarakat Bali. Untuk itu pemulihan sektor pariwisata perlu untuk segera di lakukan.

\subsection{Upaya Pemulihan Pariwisata di Ten- gah Pandemi}

Melihat berbagai dampak dari COVID19 terhadap sektor pariwisata yang berpengaruh terhadap penurunan perekonomian khususnya di Pulau Bali serta seluruh daerah di Indonesia perlu diteliti upaya-upaya yang dapat dilakukan untuk memulihkan sektor pariwisata di tengah pandemi COVID-19 yang masih belum usai. Diperlukan berbagai 
upaya untuk dapat memulihkan sektor pariwisata seperti sediakala. Berbagai usulan disampaikan oleh para ahli sebagai upaya untuk memulihkan sektor pariwisata. Wakil Rektor I Universitas Widya Mataram (UWM) Dr. Jumadi, SE., MM, dalam Acara Webinar bertajuk Pemulihan Sektor UMKM dan Pariwisata Pasca Pandemi Covid-19, mengungkapkan bahwa pemulihan sektor pariwisata dapat dilakukan dengan penanganan jangka pendek, menengah dan panjang. Penanganan jangka pendek dengan memberikan dukungan finansial atau stimulus terhadap biaya operasional dan para pelaku industri pariwisata. Solusi lain dengan mengoptimalkan Kelompok Sadar Wisata (POKDARWIS), penguatan regulasi bagi wisatawan mancanegara, serta inovasi produk digital. Pendapat yang lain disampaikan oleh Ketua Ikatan Cendekia Pariwisata Indonesia (ICPI) Azril Azhari yaitu untuk memulihkan sektor pariwisata yang harus disiapkan terlebih dahulu adalah perbaikan 5 kelemahan daya saing pariwisata. Mulai dari kebersihan, keamanan, service infrastruktur,kesiapan hingga sustainability. Nia Niscaya, Deputi Bidang Pemasaran Kementerian Pariwista dan Ekonomi Kreatir (Kemenparekraf) mengatakan, mengembalikan kepercayaan wisatawan dianggap sebagai kunci sukses dalam upaya pemulihan sektor pariwisata di Tanah Air. Menteri Pariwisata dan Ekonomi Kreatif (Menparekraf) Wishnutama menuturkan untuk pemulihan sektor pariwisata, pihaknya akan fokus menggarap wisatawan nusantara (wisnus) lebih dulu untuk memulihkan sektor pariwisata usai terdampak berat pandemi Covid-19. Sedangkan wakil Gubernur Bali Tjokorda Oka Artha Ardhana Sukawati mengatakan bahwa membangun pariwisata Bali pasca pandemik bukanlah hal yang mudah. Implementasi protokol kesehatan pada seluruh sektor, terutama industri pariwisata, menjadi fokus utama. Berdasarkan masukan yang disampaikan oleh para ahli di sektor pariwisata, upaya-upaya yang dapat dilakukan untuk memulihkan sektor pariwisata adalah:

\subsubsection{Menerapkan Program CHS (Cleanliness, Healthy dan Safety)}

Bali ditetapkan sebagai pilot projct oleh Kemenparekraf untuk penerapan program Cleanliness, Health and Safety (CHS) dan mendorong pengelola usaha pariwisata lainnya, seperti hotel dan restoran sebagai strategi mempercepat pemulihan sektor pariwisata dan ekonomi kreatif. Langkah awal yang dapat dilakukan untuk memulihkan sektor pariwisata adalah mengembalikan kepercayaan masyarakat untuk berwisata yang aman. Pemerintah melalui Kemenparekraf telah membuat berbagai program yang bertujuan untuk menekan penyebaran virus korona di tengah tatanan kenormalan baru / new normal sebagai upaya pemulihan sektor pariwisata. Program CHS (cleanliness, Healthy dan Safety) merupakan program dari Kemenparekraf dalam beradaptasi dengan kondisi kenormalan baru "new normal" di sektor pariwisata dan ekonomi kreatif. Program ini dibuat melihat kondisi saat ini dimana virus Corona masih berada di tengah-tengah masyarakat. Program CHS merupakan salah satu jawaban untuk mengatasi ketakutan wisatawan untuk berkunjung ke suatu destinasi wisata. Wisatawan akan lebih memperhatikan protokol-protokol wisata, terutama yang terkait dengan kesehatan, keamanan, kenyamanan. Adapun konsep CHS di sektor pariwisata dan ekonomi kreatif ini mengacu kepada protokol kesehatan kementerian kesehatan, konsep pembangunan pariwisata berkelanjutan, serta sapta pesona. Tujuan dari program CHS ini adalah untuk meningkatkan kepercayaan wisatawan terhadap destinasi dan industri pariwisata Indonesia pasca pandemi COVID-19 sehingga mendorong peningkatan kunjungan wisatawan ke Indonesia. 
Adapun unsur-unsur pokok dari Program CHS dari Kemenparekraf yang harus diterapkan di setiap destinasi wisata antara lain:

1) Cleanliness atau kebersihan yaitu keadaan bebas dari kotoran seperti debu, sampah, bau serta bebas dari virus, bakteri patogen, dan bahan kimia. Menjaga Kebersihan sebagai bagian dari protokol kesehatan dan sapta pesona merupakan langkah awal dalam mencegah munculnya berbagai penyakit. Kebersihan baik itu kebersihan lingkungan maupun kebersihan diri harus ditingkatkan.

2) Health ( kesehatan) mengacu pada layanan yang menerapkan aturan kesehatan terhadap manusia dan lingkungan melalui kegiatan pencegahan, perawatan, pemantauan dan pengendalian. Tubuh yang sehat dan kuat dengan menerapkan perilaku hidup bersih dan sehat dapat menangkal dari terjangkitnya berbagai penyakit.

3) Safety atau keselamatan yaitu: keadaan bebas dari risiko, bahaya, pencemaran, ancaman, ganguan yang bersifat permanen dan nonpermanen termasuk bebas dari bahaya fisik dan nonfisik di suatu tempat dan waktu tertentu untuk mengelola, melindungi dan meningkatkan kewaspadaan masyarakat, pengunjung dan kualitas lingkungan. safety ini dapat

4) Zero wash Management, yaitu konsep yang merujuk pada strategi dan penerapan kebijakan pengelolaan sampah yang baik oleh pengelola destinasi wisata. Zero wash management perlu dilakukan untuk mengurangi dan mengatasi permasalahan sampah yang selama ini menjadi problematik bagi sektor pariwisata de Bali. Dengan adanya Zero wash management, diharapkan akan mampu memperbaiki citra pariwisata Bali yang tercemat akibat berbagai pemberitaan negatif tentang sampah di Bali.

\subsubsection{Menerapkan Protokol Kesehatan Era Baru}

Selain menerapkan program CHS dari Kemenparekraf sangat penting untuk menjalankan protokol kesehatan yang telah diinstruksikan oleh pemerintah melalui Keputusan Menteri Kesehatan Republik Indonesia NOMOR HK.01.07/MENKES/382/2020 tentang protokol kesehatan bagi masyarakat di tempat dan fasilitas umum dalam rangka pencegahan dan pengendalian Corona virus disease 2019. Dalam surat keputusan ini juga diuraikan secara detail tentang protokol kesehatan di usaha akomodasi seperti hotel/homestay/asrama, serta usaha jasa makanan dan minuman yaitu restoran. Dalam surat keputusan ini di uraikan langkahlangkah yang harus dilakukan oleh pihak pengelola, karyawan serta tamu. Peran serta serta kedisiplinan dari pihak pengelola, karyawan serta tamu dalam mematuhi protokol kesehatan ini sangat diperlukan untuk memulihkan industri pariwisata dan terhindar dari virus Corona. Adapun protokol kesehatan yang ditetapkan oleh menteri kesehatan RI adalah sebagai berikut:

a. Protokol kesehatan di Hotel/Penginapan/Homestay/Asrama dan sejenisnya

Protokol kesehatan berupa langkahlangkah yang harus dilaksanakan di usaha pariwisata baik hotel maupun restoran kelompokkan menjadi 3 yaitu protokol kesehatan bagi pihak pengelola, bagi karyawan dan bagi tamu. Di butuhkan kedisiplinan serta peran aktif dari pihak pengelola, karyawan dan tamu untuk menghindari penyebaran virus Corona serta untuk memulihkan sektor pariwisata. Adapun protokol kesehatan yang bersumber dari kementerian kesehatan Republik Indonesia untuk diterapkan di hotel antara lain: 
b. Bagi Pihak Pengelola

1) Memperhatikan informasi terkini serta himbauan dan instruksi pemerintah pusat dan pemerintah daerah terkait COVID-19 di wilayahnya. Informasi ini secara berkala dapat diakses pada laman https://infeksiemerging.kemkes.go.id www.covid19.go.id, dan kebijakan pemerintah daerah setempat

2) Memastikan Seluruh pekerja hotel memahami tentang pencegahan penularan COVID-19

3) Memasang media informasi di lokasi -lokasi strategis untuk mengingatkan pengunjung agar selalu mengikuti ketentuan jaga jarak minimal 1 meter, menjaga kebersihan tangan dan kedisplinan penggunaan masker.

4) Menyediakan Handsanitizer di pintu masuk, lobby, meja resepsionis, pintu lift, dan area publik lainnya.

5) Menjaga kualitas udara dengan mengoptimalkan sirkulasi udara dan sinar matahari, serta melakukan pembersihan filter AC.

6) Melakukan pembersihan dan disinfeksi secara berkala (paling sedikit tiga kali sehari) menggunakan pembersih dan disinfekta pada area atau peralatan yang digunakan bersama seperti pegangan pintu dan tangga, tombol lift, pintu toilet dan fasilitas umum lainnya.

7) Larangan masuk bagi karyawan yang memiliki gejala demam, batuk, pilek, nyeri tenggorokan, dan/atau sesak nafas. Karyawan mengisi formulir self assessment risiko COVID-19 sebelum masuk bekerja (Form 1) dan dilakukan pemeriksaan suhu.

8) Pintu masuk/lobby:

a) Melakukan pengukuran suhu tubuh di pintu masuk tamu dan karyawan. Apabila ditemukan suhu $>37,3{ }^{\circ} \mathrm{C}$ ( 2 kali pemeriksaan dengan jarak 5 menit), tidak diperkenankan masuk kecuali dinyatakan negatif/nonreaktif COVID-19 setelah dilakukan pemeriksaan laboratorium berupa pemeriksaan RT-PCR yang berlaku 7 hari atau rapid test yang berlaku 3 hari, sebelum masuk ke hotel.

b) Petugas menanyakan dan mencatat riwayat perjalanan tamu/pengunjung dan diminta mengisi self assessment risiko COVID-19. Jika hasil self assessment memiliki risiko besar COVID-19, agar diminta melakukan pemeriksaan kesehatan ke fasilitas pelayanan kesehatan terlebih dahulu atau menunjukan hasil pemeriksaan bebas COVID-19 yang masih berlaku

c) Menerapkan jaga jarak yang dilakukan dengan berbagai cara, seperti mengatur antrian di pintu masuk, di depan meja resepsionis dengan pemberian tanda di lantai, mengatur jarak antar kursi di lobby, area publik dan lain sebagainya.

d) Menyediakan sarana untuk meminimalkan kontak dengan pengunjung misalnya pembatas/partisi mika di meja resepsionis, pelindung wajah (faceshield), penggunaan metode pembayaran non tunai, dan lainlain.

9) Kamar

a) Melakukan pembersihan dan disinfeksi pada kamar sebelum dan sesudah digunakan tamu meliputi 
pegangan pintu, meja, kursi, telephone, kulkas, remote TV dan AC, kran kamar mandi dan fasilitas lain yang sering disentuh tamu.

b) Memastikan proses pembersihan dan disinfeksi kamar dan kamar mandi, serta peralatan yang telah digunakan tamu.

c) Pastikan mengganti sarung bantal, sprei, hingga selimut dengan yang telah dicuci bersih.

d) Penyediaan handsanitizer di meja.

10) Ruang Pertemuan

a) Kapasitas untuk ballroom, meeting room, dan conference harus selalu memperhitungkan jaga jarak minimal 1 meter antar tamu dan antar karyawan. Hal ini dapat dilakukan dengan menghitung kembali jumlah undangan, pembuatan lay out ruangan, membagi acara menjadi beberapa sesi, membuat sistem antrian, dan lain sebagainya.

b) Memberikan informasi jaga jarak dan menjaga kesehatan perihal suhu tubuh, pemakaian masker pembatasan jarak dan sering cuci tangan pakai sabun dengan air mengalir atau menggunakan handsanitizer.

c) Menyediakan panduan/informasi layout jarak aman, sejak dari masuk parkiran, didalam lift, ke lobby, ke ruang pertemuan, hingga keluar parkiran.

d) Membuat konsep labirin untuk jalur antrian, jalur kirab diperlebar, dan panggung diperbesar untuk menjaga jarak.

e) Memastikan proses pembersihan dan disinfeksi ruang pertemuan sebelum dan setelah digunakan.

f) Membersihkan dan mendisinfeksi microphone setiap setelah digunakan masing-masing orang. Tidak menggunakan microphone secara bergantian sebelum dibersihkan atau menyediakan microphone pada masing-masing meja.

g) Master of Ceremony/MC harus aktif informasikan protokol kesehatan, antrian, jaga jarak, dan pemakaian masker.

\section{1) Ruang Makan}

a) Mewajibkan setiap orang yang akan masuk ruang makan untuk mencuci tangan pakai sabun dengan air mengalir.

b) Pengaturan jarak antar kursi minimal 1 meter dan tidak saling berhadapan. Dalam hal tidak dapat diterapkan pengaturan jarak dapat dilakukan upaya rekayasa teknis lain seperti pemasangan partisi antar tamu berhadapan di atas meja makan.

c) Tidak menggunakan alat makan bersama-sama. Peralatan makan di atas meja makan yang sering disentuh diganti dalam bentuk kemasan sekali pakai/sachet atau diberikan kepada pengunjung apabila diminta.

d) Mewajibkan semua penjamah pangan atau pekerja yang kontak langsung dengan pangan untuk mengenakan alat pelindung diri seperti penutup kepala, sarung tangan, celemek, dan masker. Sarung tangan harus segera diganti setelah memegang barang 
selain makanan.

e) Tidak menerapkan sistem prasmanan/buffet. Apabila menerapkan sistem prasmanan/buffet agar menempatkan petugas pelayanan pada stall yang disediakan dengan menggunakan masker serta sarung tangan, pengunjung dalam mengambil makanan dilayani oleh petugas dan tetap menjaga jarak minimal 1 meter. Semua peralatan makan wajib dibersihkan dan didisinfeksi sebelum digunakan kembali.

f) Untuk meminimalisasi pelayanan makanan secara buffet (prasmanan), juga dapat dilakukan dengan menggunakan opsi action station, set menu, nasi kotak/box/take away, individual portion dan variasi lainnya dengan jenis makanan yang tidak banyak namun kualitas lebih baik.

g) Untuk meal service ala carte, sitting party, silver service agar penjagaan jarak dan penataan kursi dan peralatan harus tetap terjaga.

12) Kolam Renang

a) Memastikan air kolam renang menggunakan desinfektan dengan clorin 1-10 ppm atau bromin 3-8 ppm sehingga $\mathrm{pH}$ air mencapai $7.2-8$ dilakukan setiap hari dan hasilnya diinformasikan di papan informasi agar dapat diketahui oleh konsumen.

b) Pengelola melakukan pembersihan dan disinfeksi terhadap seluruh permukaan disekitar kolam renang seperti tempat duduk, lantai dan lain-lain.

c) Menerapkan jaga jarak diruang ganti.

d) Pastikan tamu yang akan menggunakan kolam renang dalam keadaan sehat, dengan mengisi form self assesment risiko COVID-19 (form 1). Bila dari hasil self assesment masuk dalam kategori risiko besar tidak diperkenankan untuk berenang.

e) Batasi jumlah pengguna kolam renang agar dapat menerapkan jaga jarak.

f) Gunakan semua peralatan pribadi masing-masing

g) Gunakan masker sebelum dan setelah berenang.

13) Pusat Kebugaran

a) Membatasi kapasitas jumlah tamu yang melakukan latihan, agar dapat menerapkan prinsip jaga jarak dengan jarak antar tamu minimal 2 meter.

b) Melakukan pembersihan dan disinfeksi alat olahraga sebelum dan setelah digunakan.

c) Menyediakan handsanitizer di masing-masing alat.

d) Tidak boleh menggunakan alat olahraga bergantian sebelum dilakukan pembersihan dengan cara di lap menggunakan cairan disinfektan.

e) Lakukan pembersihan dan disinfeksi pada tempat-tempat yang sering disentuh seperti ruangan dan permukaan alat olahraga yang sering disentuh secara berkala disesuaikan dengan tingkat keramaian pusat kebugaran.

f) Memberikan jarak antar alat minimal 2 meter. Apabila tidak 
memungkinkan diberikan sekat pembatas untuk alat-alat kardio (treadmill, bicycle, elliptical machine).

g) Sedapat mungkin menghindari pemakaian AC, sebaiknya sirkulasi udara lewat pintu jendela terbuka.

h) Jika tetap memakai AC maka perlu diperhatikan tingkat kelembaban udara di dalam ruangan dan mengatur sirkulasi udara sebaik mungkin agar tetap kering. Disarankan memakai air purifier.

i) Peralatan seperti handuk dan matras harus dalam keadaan bersih dan sudah didisinfeksi sebelum digunakan.

j) Menggunakan masker selama berolahraga. Olahraga yang menggunakan masker dilakukan dengan intensitas ringan sampai sedang (masih dapat berbicara ketika berolahraga).

\section{4) Mushala}

a) Meminta tamu menggunakan peralatan shalat dan sajadah masing-masing.

b) Tetap menggunakan masker saat shalat.

c) Terapkan jaga jarak minimal 1 meter.

15) Fasilitas/pelayanan lainnya di hotel yang berisiko terjadinya penularan karena sulit dalam penerapan jaga jarak agar tidak dioperasikan dahulu.

a) Bagi Karyawan

(1) Memastikan diri dalam kondisi sehat sebelum berangkat bekerja. Jika mengalami gejala seperti demam, batuk, pilek, nyeri tenggorokan, dan/atau sesak nafas tetap di rumah dan periksakan diri ke fasilitas pelayanan kesehatan apabila berlanjut, serta laporkan pada pimpinan tempat kerja.

(2) Saat perjalanan dan selama bekerja selalu menggunakan masker, menjaga jarak dengan orang lain, dan hindari menyentuh area wajah. Jika terpaksa akan menyentuh area wajah pastikan tangan bersih dengan cuci tangan pakai sabun dengan air mengalir atau menggunakan handsanitizer.

(3) Menggunakan alat pelindung diri tambahan seperti sarung tangan saat melakukan pekerjaan pembersihan dan saat menangani limbah, termasuk saat membersihkan kotoran yang ada di meja restoran atau di kamar.

(4) Berpartisipasi aktif mengingatkan tamu untuk menggunakan masker dan menjaga jarak minimal 1 meter.

(5) Saat tiba di rumah, segera mandi dan berganti pakaian sebelum kontak dengan anggota keluarga di rumah. Bersihkan handphone, kacamata, tas, dan barang lainnya dengan cairan disinfektan.

(6) Meningkatkan daya tahan tubuh dengan menerapkan PHBS (perilaku hidup bersih dan sehat) seperti mengkonsumsi gizi seimbang, aktivitas fisik minimal 30 menit sehari dan istirahat yang cukup dengan tidur minimal 7 jam, serta menghindari faktor risiko penyakit. 
b) Bagi Tamu

(1) Memastikan diri dalam kondisi sehat sebelum keluar rumah, Jika mengalami gejala seperti demam, batuk, pilek, nyeri tenggorokan, dan/atau sesak nafas tetap di rumah dan periksakan diri ke fasilitas pelayanan kesehatan apabila berlanjut.

(2) Selalu menggunakan masker selama perjalanan dan saat berada di area publik.

(3) Menjaga kebersihan tangan dengan sering mencuci tangan pakai sabun dengan air mengalir atau menggunakan handsanitizer.

(4) Hindari menyentuh area wajah seperti mata, hidung, dan mulut.

(5) Tetap memperhatikan jaga jarak minimal 1 meter dengan orang lain.

(6) Membawa alat pribadi termasuk peralatan ibadah sendiri seperti alat sholat

\subsubsection{Protokol Kesehatan Untuk di terapkan di Rumah Makan/Restoran dan sejenisnya}

a. Bagi Pelaku Usaha

1) Memperhatikan informasi terkini serta himbauan dan instruksi pemerintah pusat dan pemerintah daerah terkait COVID-19 di wilayahnya. Informasi secara berkala dapat diakses pada laman https://infeksiemerging.kemkes.go.id, www.covid19.go.id, dan kebijakan pemerintah daerah setempat.

2) Menyediakan sarana cuci tangan pakai sabun atau handsanitizer di pintu masuk dan tempat lain yang mudah diakses pengunjung.

3) Mewajibkan setiap orang yang akan masuk untuk mencuci tangan pakai sabun dengan air mengalir atau menggunakan handsanitizer.

4) Mewajibkan pekerja menggunakan masker selama bekerja.

5) Pastikan pekerja memahami COVID19 dan cara pencegahannya.

6) Larangan masuk bagi pekerja dan pengunjung yang memiliki gejala demam, batuk, pilek, nyeri tenggorokan, sesak nafas, dan/atau diare atau memiliki riwayat kontak dengan orang terkena COVID-19.

7) Melakukan pemeriksaan suhu tubuh di pintu masuk. Jika ditemukan pekerja atau pengunjung dengan suhu $>37,3^{\circ} \mathrm{C}$ ( 2 kali pemeriksaan dengan jarak 5 menit) tidak diperkenankan masuk.

8) Mewajibkan semua penjamah pangan atau pekerja yang kontak langsung dengan pangan agar mengenakan masker, sarung tangan, atau penjepit pada saat menyentuh pangan siap saji dan mengenakan penutup kepala dan celemek pada saat persiapan, pengolahan, dan penyajian pangan. Penggunaan sarung tangan sesuai dengan standar keamanan pangan yang berlaku.

9) Menyediakan alat bantu seperti sarung tangan dan/atau penjepit pangan untuk meminimalkan kontak langsung dengan pangan siap saji dalam proses persiapan, pengolahan, dan penyajian.

10) Tidak menerapkan sistem prasmanan/buffet. Apabila menerapkan sistem prasmanan/buffet agar menempatkan petugas pelayanan pada stall yang disediakan dengan menggunakan masker serta sarung tangan, pengunjung dalam mengambil makanan dilayani oleh petugas dan tetap menjaga jarak minimal 1 meter. Semua peralatan makan wajib 
dibersihkan dan didisinfeksi sebelum digunakan kembali.

11) Menjaga kualitas udara di tempat usaha atau di tempat kerja dengan mengoptimalkan sirkulasi udara dan sinar matahari masuk serta pembersihan filter AC.

12) Mengupayakan pembayaran secara nontunai (cashless) dengan memperhatikan disinfeksi untuk mesin pembayaran. Jika harus bertransaksi dengan uang tunai, gunakan handsanitizer setelahnya.

13) Memastikan seluruh lingkungan restoran/rumah makan dalam kondisi bersih dan saniter dengan melakukan pembersihan dan disinfeksi secara berkala minimal 2 kali sehari (saat sebelum buka dan tutup) menggunakan pembersih dan disinfektan yang sesuai.

14) Meningkatkan frekuensi pembersihan dan disinfeksi (paling sedikit 3 kali sehari) terutama pada permukaan area dan peralatan yang sering disentuh/dilewati orang seperti meja dan kursi di ruang makan, kenop/gagang pintu, sakelar, kran, tuas flush toilet, toilet, meja kasir, mesin penghitung uang/kasir, lantai ruang makan, dan lain lain.

15) Menutup alat makan yang diletakkan di meja makan (sendok, garpu, pisau dibungkus misalnya dengan tissue).

16) Tidak menggunakan alat makan bersama-sama. Peralatan makan di atas meja makan yang sering disentuh diganti dalam bentuk kemasan sekali pakai/sachet atau diberikan kepada pengunjung apabila diminta.

17) Menerapkan jaga jarak dengan berbagai cara seperti:

a) Mengatur jarak minimal 1 meter pada saat antri masuk rumah makan/restoran dan sejenisnya, memesan, dan membayar di kasir dengan memberikan tanda di lantai. Bila memungkinkan ada pembatas pengunjung dengan kasir berupa dinding plastik atau kaca.

b) Pengaturan jarak antar kursi minimal 1 meter dan tidak saling berhadapan atau pemasangan partisi $\mathrm{kaca} / \mathrm{mika} /$ plastik antar tamu di atas meja makan.

18) Meningkatkan pelayanan pemesanan makanan dan minuman secara online atau delivery service atau drive thru, dan lain sebagainya.

b. Bagi Pekerja

1) Memastikan diri dalam kondisi sehat sebelum keluar rumah, Jika mengalami gejala seperti demam, batuk, pilek, nyeri tenggorokan, dan/atau sesak nafas tetap di rumah dan periksakan diri ke fasilitas pelayanan kesehatan apabila berlanjut, serta laporkan pada pimpinan tempat kerja.

2) Menggunakan masker saat perjalanan dan selama berada di tempat kerja.

3) Hindari menyentuh wajah, mata, hidung, dan mulut.

4) Memperhatikan jaga jarak minimal 1 meter dengan orang lain.

5) Menggunakan pakaian khusus saat bekerja.

6) Menghindari penggunaan alat pribadi secara bersama seperti alat sholat, alat makan, dan lain-lain.

7) Segera mandi dan berganti pakaian sebelum kontak dengan anggota keluarga di rumah.

8) Jika diperlukan, bersihkan handphone, kacamata, tas, dan barang lainnya dengan cairan disinfektan. 
9) Saat tiba di rumah, segera mandi dan berganti pakaian sebelum kontak dengan anggota keluarga di rumah. Bersihkan handphone, kacamata, tas, dan barang lainnya dengan cairan disinfektan.

10) Meningkatkan daya tahan tubuh dengan menerapkan PHBS seperti mengkonsumsi gizi seimbang, aktivitas fisik minimal 30 menit sehari dan istirahat yang cukup dengan tidur minimal 7 jam, serta menghindari faktor risiko penyakit.

c. Bagi Pengunjung/Konsumen

1) Memastikan diri dalam kondisi sehat sebelum berkunjung ke rumah makan/restoran atau sejenisnya. Jika mengalami gejala seperti demam, batuk, pilek, nyeri tenggorokan, dan/atau sesak nafas tetap di rumah dan periksakan diri ke fasilitas pelayanan kesehatan apabila berlanjut.

2) Saat perjalanan dan selama bekerja selalu menggunakan masker, menjaga jarak dengan orang lain, dan hindari menyentuh area wajah. Jika terpaksa akan menyentuh area wajah pastikan tangan bersih dengan cuci tangan pakai sabun dengan air mengalir atau menggunakan handsanitizer.

3) Saat tiba di rumah, segera mandi dan berganti pakaian sebelum kontak dengan anggota keluarga di rumah.

4) Bersihkan handphone, kacamata, tas, dan barang lainnya dengan cairan disinfektan.

5) Meningkatkan daya tahan tubuh dengan menerapkan PHBS seperti mengkonsumsi gizi seimbang, aktivitas fisik minimal 30 menit sehari dan istirahat yang cukup dengan tidur minimal 7 jam, serta menghindari faktor risiko penyakit.

\subsection{Promosi Wisata}

Setelah program CHS serta protokol kesehatan telah dilaksanakan maka upaya selanjutnya yang dapat dilakukan adalah mempromosikan Bali sebagai destinasi wisata yang aman untuk di kunjungi. Adapun upaya promosi yang dapat dilakukan adalah menjalin kerjasama dengan maskapai negara asing, online travel agernt, influencer dalam hal untuk mendatangkan wisatawan asing untuk berwisata ke Bali.

Langkah promosi berikutnya yang dapat dilakukan adalah dengan melakukan kampanye-kampanye baik itu berupa iklan untuk menciptakan image bahwa Bali sudah siap menerima tamu serta aman untuk dikunjungi. Diperlukan kerjasama dan peran serta dari semua pihak terutama pelaku wisata untuk mempromosikan tentang kondisi Bali yang aman untuk di kunjungi.

\section{PENUTUP}

Penyebaran virus Corona yang sangat luas telah menghantam sektor pariwisata di Bali maupun sektor pariwisata secara global. Pandemi COVID-19 yang sangat berbahaya bagi kesehatan telah menyebabkan ketakutan masyarakat untuk melakukan perjalanan. Selain itu adanya kebijakan seperti social distancting serta lockdown dan larangan bepergian ke luar negeri telah menyebabkan penurunan kunjungan wisawatan ke Bali secara drastis. Tidak adanya wisatawan baik itu wisatawan domestik maupun wisatawan asing ke Bali telah melumpuhkan sektor pariwisata Bali. Dampaknya sangat dirasakan oleh masyarakat Bali yang mayoritas bekerja di sektor pariwisata. Ribuan masyarakat Bali di PHK dan di rumahkan. Perekonomian masyarakat Bali pun terguncang. Meskipun pandemi COVID-19 belum berakhir namun perlu dilakukan upaya-upaya untuk memulihkan sektor pariwisata di Bali untuk menjaga kestabilan ekonomi khususnya masyarakat Bali. 
Salah satu kunci utama dalam memulihkan sektor pariwisata adalah mengembalikan kepercayaan untuk berwisata. Bali ditetapkan sebagai pilot projct oleh Kemenparekraf untuk penerapan program CHS (Cleanliness, Health and Safety). Salah satu upaya yang dilakukan untuk memulihkan kepercayaan wisatawan untuk berkunjung ke Bali adalah dengan menerapkan kebersihan, kesehatan, dan keamanan . Cleanliness atau kebersihan diwujudkan dengan menjaga kebersihan lingkungan kerja dan kebersihan diri agar terhindar dari penyakit. Health ( kesehatan) mengacu pada penerapan aturan kesehatan terhadap manusia dan lingkungan dengan menerapkan perilaku hidup bersih dan sehat dapat menangkal dari terjangkitnya berbagai penyakit. Safety atau keselamatan merupakan keadaan bebas dari risiko, bahaya, pencemaran, ancaman, ganguan yang bersifat permanen dan nonpermanen termasuk bebas dari bahaya fisik dan nonfisik di suatu tempat dan waktu tertentu untuk mengelola, melindungi dan meningkatkan kewaspadaan masyarakat, pengunjung dan kualitas lingkungan. Zero wash Management, penerapan kebijakan pengelolaan sampah yang baik oleh pengelola destinasi wisata. Dengan adanya Zero wash management, diharapkan akan mampu memperbaiki citra pariwisata Bali yang tercemar akibat berbagai pemberitaan negatif tentang sampah di Bali. Selain menjalankan program CHS, langkah berikutnya adalah menerapkan protokol kesehatan yang telah disusun oleh menteri kesehatan. Dalam Protokol kesehatan diuraikan tentang langkah-langkah yang harus diakukan oleh pihak pengelola, karyawan serta tamu dalam mencegah penyebaran virus Corona baik di hotel maupun di restoran. Setelah mampu menjalankan program CHS dan melaksanakan protokol kesehatan maka langkah selanjutnya adalah mempromosikan kepada dunia bahwa Bali merupakan destinasi wisata yang aman untuk dikunjungi serta menjalin kerjasama dengan pihak-pihak . Dengan adanya upaya-upaya tersebut diharapkan mampu memulihkan sektor pariwisata Bali.

\section{DAFTAR PUSTAKA}

Badan Pusat statistik Provinsi Bali, 2020, Proyeksi Penduduk Provinsi Bali Menurut Kabupaten/Kota dan Jenis Kelamin 20112020, diunduh tanggal: 15 Juni 2020, tersedia di: $\quad$ https://bali.bps.go.id/dynamictable/2016/05/13/19/proyeksipenduduk-provinsi-bali-menurut-kabupatenkota-dan-jenis-kelamin-2011-2020.html

Badan Nasional penanggulangan Bencana, 2017, Definisi Bencana, diunduh tanggal 26 Juli 20202, tersedia di: https://bnpb.go.id/definisi-bencana

Dinas Kesehatan Pemerintah Provinsi Bali, 2020, Info Kesehatan: Perkembangan Penyebaran Virus Corona cited 20 July 2020). Available from: https://www.diskes.baliprov.go.id/portfolio/ perkembangan-penyebaran-virus-corona/

Guru Pendidikan. 2020. Pengertian Pariwisata, diunduh tanggal: 20 Juli 2020, terdapat di: https://www.gurupendidikan.co.id/pariwisata/

Harian Bali Express. 2020. Dampak Pandemi Covid-19, 17.300 Lebih Pekerja Di Bali Dirumahkan, diunduh tanggal 20 Juli 2020, Tersedia di:https://baliexpress.jawapos.com/read/202 0/04/06/187484/dampak-pandemi-covid-1917300-lebih-pekerja-di-bali-dirumahkan

Herdiana, Dian. 2020. Rekomendasi Kebijakan Pemulihan Pariwisata Pasca Wabah Corona Virus Disease 2019 (Covid-19) Di Kota Bandung.

Kantor staf Presiden. 2020. Berharap Pulihnya Sektor Pariwisata Pasca Pandemi 
Covid-19 (Cited 25 July 2020). Available from:

http://ksp.go.id/berharap-pulihnya-sektorpariwisata-pasca-pandemi-covid19/index.html

Kompas.com. 2020. "Dampak Virus Corona di Bali, 800 PHK dan 46.000 Pekerja Dirumahkan"diunduh tanggal 26 Jli 2020, tersedia di:, https://denpasar.kompas.com/read/2020/04/ 13/18115961/dampak-virus-corona-di-bali800-phk-dan-46000-pekerja-dirumahkan.

Kompas.com, 2020, "Dampak Pandemi Covid-19, Pariwisata Bali Rugi Rp 9,7 Triliun Tiap Bulan", diunduh tanggal 26 Juli 2020, tersedia di: https://regional.kompas.com/read/2020/05/13/175910 91/dampak-pandemi-covid-19-pariwisatabali-rugi-rp-97-triliun-tiap-bulan.

Kemenparekraf. 2020. Program CHS di Sektor Pariwisata dan Ekonomi Kreatif, diunduh pada: 15 Juni 202, Tersedia di: https://pedulicovid19.ke-

menparekraf.go.id/program-chs-di-sektorpariwisata-dan-ekonomi-kreatif/

Kemenkeu. 2009. UNDANG-UNDANG REPUBLIK INDONESIA NOMOR 10 TAHUN 2009 TENTANG KEPARIWISATAAN,diunduh tangal: 10/06/20, terseida di, https://jdih.kemenkeu.go.id/fullText/2009/10TAHUN2009UU. HTM

Kominfo. 2016. Paparan Kementerian Pariwisata Ri Untuk Kidi ke-6, diunduh tanggal: 20 Juni 2020, tersedia di: https://web.kominfo.go.id/sites/default/files/Paparan\%20Ke$\underline{\text { menpar\%20untuk\%20KIDI\%202016.pdf }}$

Kemdikbud. 2020. Memahami Istilah Endemi, Epidemi, Dan Pandemi, diunduh 24 Juli 2020, tersedia di https://itjen.kemdikbud.go.id/public/post/det ail/memahami-istilah-endemi-epidemi-danpandemi
Kemkes. 2020. TENTANG NOVEL CORONAVIRUS (NCOV), diunduh 24 Juli 2020 , Tersedia

di: https://www.kemkes.go.id/resources/download/info-terkini/COVID19/TENTANG\%20NOVEL\%20CORONA VIRUS.pdf

Kemenparekraf. 2019.Siaran Pers: Pariwisata Diproyeksikan Jadi Penyumbang Devisa Terbesar Lima Tahun ke Depan, diunduh tanggal:13 Juni 2020, tersedia di https://www.kemenparekraf.go.id/index.php/post/siaran-pers-pariwisata-diproyeksikan-jadi-penyumbang-devisaterbesar-lima-tahun-ke-depan

Kementerian Pariwisata Republik Indonesia. 2019. Laporan akuntabilitas kinerja tahun 2018, diunduh 15 Juni 2020, tersedia di: http://eperformance.kemenpar.go.id/dokumen/254083LAKIP\%20KEMENPAR\%20T A\%202018\%20update\%2014-Juni-2019.pdf

Menteri Kesehatan Republik Indonesia. 2020. Keputusan Menteri Kesehatan Republik Indonesia Nomor Hk.01.07/Menkes/382/2020 Tentang Protokol Kesehatan Bagi Masyarakat Di Tempat Dan Fasilitas Umum Dalam Rangka Pencegahan Dan Pengendalian Corona Virus Disease 2019 (Covid-19), diunduh 25 Juli 2020, tersedia di: https://covid19.go.id/storage/app/media/Regulasi/KMK\%20No.\%20HK.01.07MENKES-382-

2020\%20ttg\%20Proto-

kol\%20Kesehatan\%20Bagi\%20Masyarakat\%20di\%20Tempat\%20dan\%20Fasilitas\%20Umum\%20Dalam\%20Rangka\%20Pencegahan\%20COVID-19.pdf

Mensah,Ishmael, 2020, Unpacking The Impacts Of COVID-19 On Tourism And Repackaging The Hotel Service, Hospitalitynet.diunduh pada 15 Juni 2020, Tersedia di https://www.hospitalitynet.org/opinion/4098 657.html 
OECD. 2020.Tourism Trends and Policies 2020, diunduh tanggal: 20 Jni 2020, tersedia di

:https://www.oecd-

ilibrary.org/sites/555d8101en/in-

dex.html?itemId=/content/compo-

nent/555d8101-en

UNWTO. 2020. International tourism growth continues to outpace the global economy, diunduh tanggal 15 Juni 2020. Tersedia di https://www.unwto.org/international-

tourism-growth-continues-to-outpace-theeconomy

UNWTO. 2020. "Tourism can be a platform for overcoming the pandemic. By bringing people together, tourism can promote solidarity and trust": UN Secretary-General Antonio Guterres. Diunduh tanggal: 15 Juni 2020, tersedia di: https://www.unwto.org/news/tourism-canpromote-solidarity-un-secretary-generalantonio-guterres

Universitas Widya Mataram, 2020, Pemulihan Sektor UMKM dan Pariwisata Pasca Pandemi Covid-19, diunduh tanggal 26 Juli 2020, tersedia di http://new.widyamataram.ac.id/content/news/pemulihan-sektorumkm-dan-pariwisata-pasca-pandemicovid-19\#.Xx0vd34RWb8

WHO. 2020. Emergencies preparedness, response ; what is a pandemic, diunduh tanggal 20 Juli 2020, tersedia di: https://www.who.int/csr/disease/swineflu/fre quently_asked_questions/pandemic/en/

World Health Organization, 2020, pertanyaan dan jawaban terkait Coronavirus, diunduh 25 Juli 2020, tersedia di: https://www.who.int/indonesia/news/novelcoronavirus/qa-for-public

Zhriyah, Dewi Aminatuz, 2020, Hal Ini Jadi Kunci Pemulihan Sektor Pariwisata,bisnis.com, diunduh tanggal 26 Juli 2020, tersedia di: https://ekonomi.bisnis.com/read/20200513/1 2/1240315/hal-ini-jadi-kunci-pemulihansektor-pariwisata 